\title{
ECOLOGY OF THE RÁCKEVE-SOROKSÁR DANUBE - A REVIEW
}

\author{
CS. VADADI-FÜlÖP ${ }^{1, *}$ - G. MÉSZÁROS ${ }^{2}-$ GY. JABLONSZKY $^{1}$ - L. HUFNAGEL ${ }^{3}$ \\ ${ }^{1}$ Eötvös Loránd University \\ H-1117 Budapest, Pázmány P. sétány 1/c, Hungary \\ ${ }^{2}$ Szent István University \\ H-2100 Gödöllö, Páter K. út 1., Hungary \\ ${ }^{3}$ Corvinus University of Budapest \\ H-1118 Budapest, Villányi út 29-33, Hungary \\ e-mail:vadfulcsab@gmail.com \\ (Received $31^{\text {th }}$ Jan 2007; accepted $15^{\text {th }}$ May 2007)
}

\begin{abstract}
Present paper is a review on the Ráckeve-Soroksár Danube in ecological standpoint. The goal of this study is to collect and evaluate all of available publications in that conception, concerning this Danube arm. Phytoplankton, zooplankton, macroinvertebrates, vertebrates, macrophytes and also water chemistry, water management, geographical description are presented. The review comprises the main studies beginning with the earliest faunistic publications up to the recent ecological, multidisciplinary investigations. Spatial and temporal patterns likewise water quality are considered as important. Additionally checklist of aquatic invertebrate and vertebrate fauna are given based on data from literature.
\end{abstract}

Keywords: Danube, water quality, eutrophication, composition

\section{Introduction}

The Ráckeve-Soroksár Danube (RSD) is the second largest side arm in the Hungarian section of the river Danube, and is located between the 1642 and 1586 river kilometres (Fig. 1.). It is $58 \mathrm{~km}$ long from which $11 \mathrm{~km}$ belongs to the area of Budapest. It is enclosed by the two estaurine works Kvassay- and Tass sluices, therefore water level is manageable. The water surface is $14 \mathrm{~km}^{2}$, body of water is around 40 million $\mathrm{m}^{3}$, it can be replaced within 1,5-2,5 weeks in summer, and within 3-5 weeks in winter [18]. The current velocity is very low, $0,1-0,3 \mathrm{~m} / \mathrm{s}$. The shoreline is $120 \mathrm{~km}$ long, the shoreline length of the islands and side arms is $60 \mathrm{~km}$, so the whole shoreline is altogether $180 \mathrm{~km}$ long, which is equal to that of lake Balaton [44]. The water level fluctuation is between $20-60 \mathrm{~cm}$, the decline of water is between $10-30 \mathrm{~cm} \mathrm{[94].} \mathrm{The}$ catchment area is around $1800 \mathrm{~km}^{2}$ [87]. RSD supplied the Danube-Tisza canal, I. Árapasztó canal, Kiskunsági canal with water, moreover Gyáli creek flows into the river arm.

The aim of this work was to collect and evaluate the publications dealing with RSD in ecological conception. We felt it necessary to add some reports performed by VITUKI and KDV-KÖVIZIG and also several Internet references, as these comprise significant pieces of information which should not be ignored. However these sources are not complete. Essentially studies were discussed in chronological order. We focused on aquatic organisms, birds are not considered, on the other hand data of vertebrates, excluding fishes, is scarce. Checklist of invertebrate and vertebrate fauna is given in appendix.

So far any summary has not been written of this river section. Many investigations neglect this river arm and concentrate only on the main arm. Similar comprehensive work has been published in 1987 [19] on the Hungarian river stretch by the Little 
Hungarian Plain. The mentioned section of Danube has become great interest. IAD (International Association for Danube Research) was founded in 1956 with the goal of promoting and coordinating activities in the fields of limnology, water management and water protection in the Danube River basin [93]. Conferences have been organized regularly, special issues are available.



Figure 1. Location of RSD within river Danube.

\section{Physical geographical summary of RSD and its area}

Ráckevei (Soroksári) Danube arm (hereafter RSD) is located on there the Csepelisík, mostly south of Budapest, besides in north at Pesterzsébet, Soroksár and Dunaharaszti smaller segment of the arm assorts with the Pesti hordalékkúp-síkság (alluvium plain of Pest). However surveying the environment of the river arm we should consider the features of the „small-scene” Csepeli-sík.

Csepeli-sík, which is the part of the Dunamenti-síkság (plain inshore the Danube), is a juvenlie formation in geological aspect. Its momentous element is the 10-20 meter gross fluvial pebble stone strata, which had been deposited on Pannonian sediments. This strata which is able to keep huge amount of water constitutes notable pebble stone resources as well, mostly in Szigetszentmiklós, Kiskunlacháza, Bugyi, Délegyháza, Adony, Dunavarsány and Halásztelek [50]. Above the coarse-grained pebble stone and sand strata there are younger sediments of the floodplain: slobby and loamy formations on lower floodplains or rather spillage slob and sand on higher floodplains. In this surface fluvial shifting sand occurs as well [49]. Csepel island had envolved and progressed in late pleistocene and through the whole holocene. The two river arms around the island had came off in river basins determinated tectonically [36]. 
The elevation in the small-scene is between 95 and 168 meters and the relief parameters are allotted by a gentle north-south directed decrease of altitude, in addition a moderated gradient is noticeable towards the Danube [50]. This area is diversified by numerous abandoned river basins and quondam littoral dunes besides in east surfaces emerge of the floodplain composed by shifting sand [50].

RSD is around 56 kilometers long and its whole catchment area is 1411 square kilometers stand. Gyáli-csatorna, Duna-Tisza csatorna and Északi övcsatorna canals also empty into the RSD, where the fluctuation of water level exists smoothly, modulated artificially by Kvassay and Tassi sluices standing on the two ends [50]. Before the regulation works of RSD, the tierce amount of Danube's runoff had passed through the RSD, but nowdays the extent of runoff is only $30 \mathrm{~m}^{3} / \mathrm{s}$ [65]. This is the main reason of continuous and relatively facile depositioning and filling up of river drift's in $\mathrm{RSD}$, where the water is reasonably contaminated, chiefly in view of unclarified sewage inlet [50].

Subsoil waters avarage level is 2-4 $\mathrm{m}$, however the quality of these waters frequently inadequate partly because of settlements deficient sewage systems. Underground waters standing deeper than the mentioned subsoil waters do not jar with the subsoil waters above, and there ate numerouos artesian wells [50].

RSD's area is a temperately warm, dry climated small-scene [50]. The mean annual temperature is fluctuateing between 10,2 and $10,3{ }^{\circ} \mathrm{C}$ and on the avarage there are 204208 days a year without frost besides the mean temperature is above $10^{\circ} \mathrm{C}$ through 192 194 days [50]. The tract belongs to the Hungarian Great Plane's middle (if so dry) climatic sector and the number of sunshine hours exceeds 2000 a year. [3]. The dominant direction of wind is north-western, annual amount of fall exists between 530 and $580 \mathrm{~mm}$ and $300-320 \mathrm{~mm}$ of this all totality falls on vegetation period besides usually there are 20 days a year when blanket of snow is expected [50].

The soils of Csepeli-sík show so fair variablity. In the aggregate there are 13 types of soils, nevertheless none of them measures up to $20 \%$ of the whole territory in the smallscene. In higher surfaces we can mostly find substantial chernozem soils (frequently effected by water) besides on lower surfaces there are chiefly different types of alluvial meadow soils which graduate into clayey meadow soils in south direction [66]. In south solonchak and solonec soils are prevalent in which partly specific saline associations had come into existence.

The small-scene belongs to the Duna-Tisza közi flora provice, accordingly the following assosiations exist there: Convallario-Quercetum roboris danubiale, Junipereto-populetum albae, Querco-robori-Carpinetum hungaricum, besides diverse other associations are also frequent there [49]. In agricultural land corn, fodder corn and alfalfa are the main crops [50] besides in sanded soils viniculture is also occurrent.

\section{History and division for sections}

In the 19th century the Danube was split into two arms: Budafok and Soroksár arms. Neither was regarded as the main arm. The flood in 1838 was caused by the unregulated river bed, because packs evolved for the sake of the disordered, shoaly river section. Water level raised and it led to disaster. After the flood, Budafok arm was designated as main arm, Soroksár arm was enclosed with the Gubacsi dam in 1873 (located by the Gubacsi bridge) [70]. Kvassay and Tass sluices were built in the 10s and 20s. Detailed description is available in Bognár's [8] work. Kvassay power plant started up in 1962. 
The subdivision began at the $60 \mathrm{~s}$ and realization of the shoreline and islands. Between the years 1979-1985, the river bed of the upper $10 \mathrm{~km}$ long river section was regulated, water current capacity increased up to $50 \mathrm{~m}^{3} \mathrm{~s}^{-1}$. Main functions of Kvassay sluice are providing the water supply and the operational water level, additionally precluding the floods existing on Danube [94].

The Danube arm could be devided into three typical sections. The upper section (38$58 \mathrm{rkm}$ ) alters most dinamically that is caused by the large amounts of mud. The river bed is shallow (2-3 m) and narrow $(80-200 \mathrm{~m})$, that is why the highest current velocity could be observed here. However this velocity is substantially lower as compared with the Danube, which has several effects. Primarily the floating matter settles here transported from Danube and pollution is intense. Next section $(22-38 \mathrm{rkm})$ is deeper and wider (average bed width 350-400 $\mathrm{m}$, water depth 2,5-3 m), body of water is 16-18 million $^{3}$. Extended reeds and swamps are characteristic of this stretch that extends between Szigethalom and Ráckeve. The lower section (0-22 rkm), located between Ráckeve and Tass sluice, has a bed width of $300 \mathrm{~m}$, and water depth of 3,5-6 m. Body of water is 20-25 million $\mathrm{m}^{3}$ that adds up to $50-55 \%$ of the whole water body of RSD [87]. Reeds can be found only in the narrow shore zone. Current velocity is verly low, it can be regarded as a stagnant water. Water quality is most favourable here, mostly suitable for fishing. Fig. 2. shows the RSD with the sampling sites, settlements and important works.

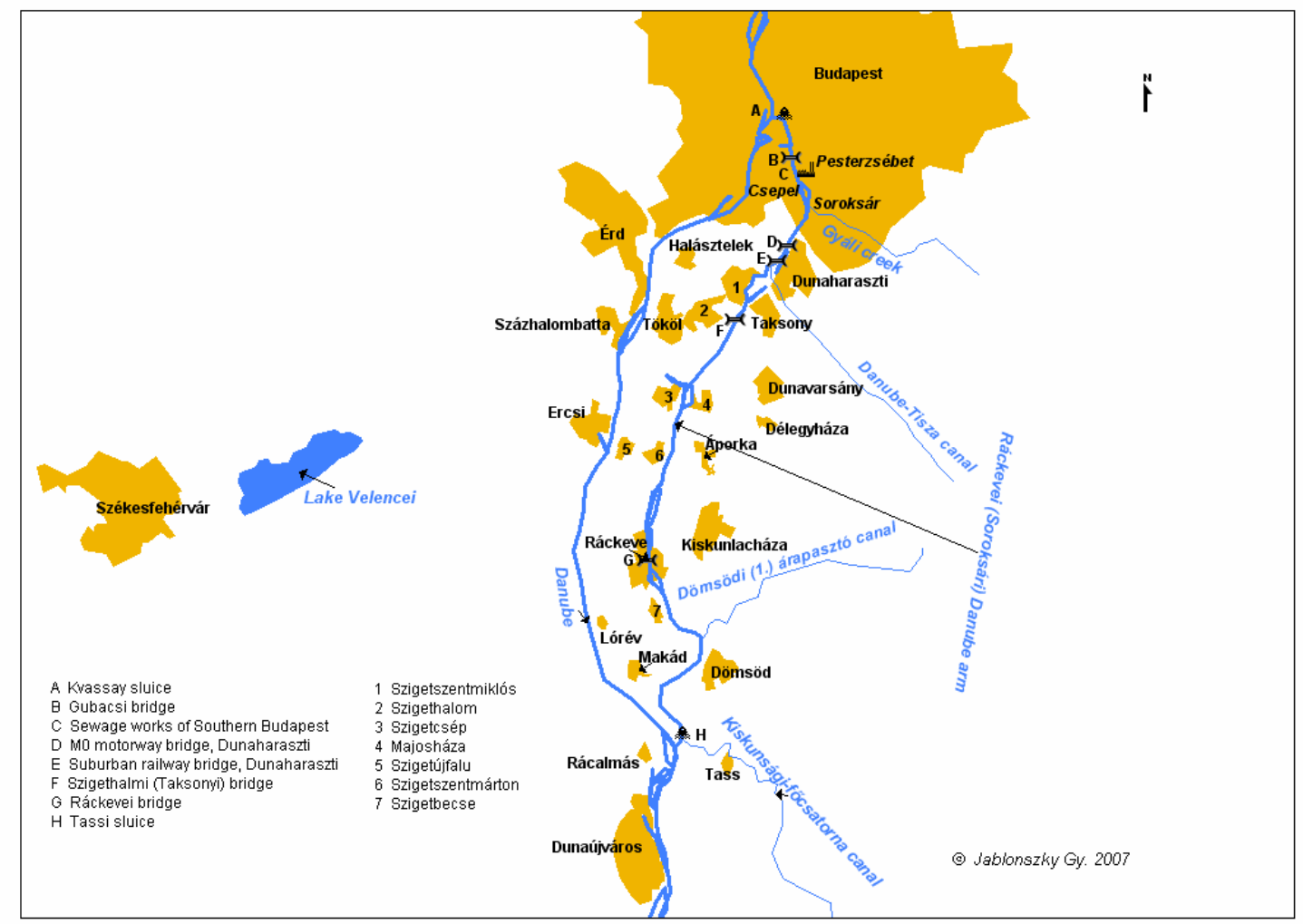

Figure 1. Map of RSD with sampling sites, settlements, important bridges and works. 


\section{Water management}

The close position to the capital and the regulated character of RSD permit of numerous water management utilizations on RSD. Duna-Tisza canal, I. Árapasztó canal and Kiskunsági canal get water from RSD, making it possible to water several agricultural areas. Most amount of water gets the Kiskunsági canal $\left(15 \mathrm{~m}^{3} / \mathrm{s}\right)$ [94]. During the watering season (between $1^{\text {th }}$ April and $30^{\text {th }}$ September) water level is taken higher than during beyond the watering season (between $1^{\text {th }}$ October and $31^{\text {th }}$ March), but it means only few decimetres fluctuation in water level. Average runoff is taken out from Duna-Tisza canal and from I. Árapasztó canal, is $2 \mathrm{~m}^{3} / \mathrm{s}$ during watering season. However the former takes water back to the RSD with an average $1 \mathrm{~m}^{3} / \mathrm{s}$ runoff in case of inland waters. The side arm as water-way is of little amount in our days, shipping has been ceased. Estuarine works hold up put in and out and also swells are objectionable [89]. The large water surface, long and structured shore line, position, favourable water temperature and rich fauna adapt the Ráckeve-Soroksár Danube for recreation, aquatic sports and fishing. Concerning angling, the side arm has been one of the most significant water in Hungary for a long time [18]. The upper section is suitable for aquatic sports, middle section for fishing and lower section for fishing and bathing [68]. Many demands of exploitation exist, which are the following: watering, industrial water usage, diversion of inland waters, water for fishponds, recreation, aquatic sports, fishing and also shipping earlier [56].

Continual water input by Kvassay sluice is a deciding factor, because of the loading of wastewater, which should be diluted and mixed. By low water levels, water can not flow gravitationally into RSD, so it must be pumped by Kvassay sluice [94].

\section{Water quality and bacterological investigations}

Complex water qualtiy analysis on RSD has been started in the 50s. Lesenyei [47], and Szabó [91] described the then components of wastewaters loaded into RSD. Both chemical and biological examinations were applied to determine the effect of wastewaters. Most cases the water proved to be beta-mesosaprobic. The effect of pollution decreased explicitly at the river $\mathrm{km} \mathrm{40,} \mathrm{while} \mathrm{at} \mathrm{the} \mathrm{river} \mathrm{km} 30$ no effect was detectable. Most pollution came from Torontal street (at that time there was no sewage farm).

Papp [54] published water quality data concerning Hungarian surface waters based on data series of 10 years. According to the author, RSD can be characterized as follows: oxygen consumption (6,1-10 mg/l; polluted), chloride content (10,1-20 mg/l; medium), sulfate content (20,1-50 mg/l; medium), hardness (8,1-15; moderate), total dissolved solid content (201-500 mg/l; medium), Coli pollution (11-1000 ind $/ \mathrm{ml}$; moderately polluted respectively polluted). RSD can be characterized by a little alkaline PH [90].

VITUKI [84] made an assessment between 1963 and 1969 and pointed out, that no change in water quality set in at that period. However the content of ammonium ion and nitrate increased, which refered to the cumulative pollution. Other study performed by VITUKI in 1975 stated [85] that conductivity and toxicity did not change during the survey and are not worrying. Based on calculations, nutrient content of wastewaters in itself, is sufficient for eutrophication in RSD.

Schiefner and Urbányi [64] took samples from the river arm in 1966-67. Dissolved oxygen content was on the average $10,8 \mathrm{mg} / 1$, value of total hardness was 14 , sulfate 
content ranged between $20-50 \mathrm{mg} / \mathrm{l}$. After the water quality assessment method of Papp [54], water was moderately polluted up to Majosháza and clean up to Tass based on Coli pollution, whereas moderately polluted based on organic matter content.

In terms of bacterial pollution RSD was devided into two parts after Ulrich et al. [76]: above and below Majosháza. The river stretch above Majosháza is much more polluted. Wastewater creates no effect below Majosháza, the capacity of selfpurification is due to the slow current velocity.

Némedi et al. [52] took samples from the river arm in the years 1979-1980. They compared their results with the state existed in 1953 and stated, that the bacterological pollution have not changed substantially between 1953-1980. The decreasing number of wastewaters loaded into RSD have made a temporary improvement in water quality at the beginning the 60s, but data published between 1969-1974 showed that the river arm is overloaded. Bacterological pollution is higher in RSD in the range of the capital, than in the main arm of Danube under Budapest (dilution of wastewater in Danube is 157fold, while in RSD only 32-fold). Conditions for self-purification of RSD is more unfavourable as compared to the Danube, because of the current velocity, dilution, toxicity and oxygen supply conditions.

Varga et al. [77] published water quality data between 1980-1984. According to the writers, water quality problems occur twice in a year. First in winter, when ice covers the water, self-purification process slows down and oxygen deficiency sets in, secondly in late summer, when algal blooms occur (oft 50 million ind/litre). The ice cover period takes approximately 40-50 days long. Above mentioned problems indicate, that the loadability of the river arm has been reached its limits.

After Dévényi [18], water quality of RSD is determined by the following: water loaded from Danube, wastewaters, loading of inland waters and rainwaters, selfpurification process, polluted mud, algal blooms. Water quality of the upper section is influenced primarily by the quality and quantity of water derived from Danube. The author analysed the water quality between 1979-1989 based on chemical and biological measurements performed by VIZIG. Total dissolved solid content was on the average between 300 and $335 \mathrm{mg} / \mathrm{l}$, so it is in keeping with Papp [54]. Water was most polluted between Kvassay sluice and Szigethalom, under Szigethalom water quality improved gradually. Finally he stated, that the biological state of RSD has been declined to a less degree between the years 1979-1989, which manifests in the increasing level of saprobity. Based on bacterological examinations RSD was polluted respectively moderately polluted, similar to Papp's [54] results. Bathing facilities existed only at the lower river section for the sake of bacterological pollution.

In accordance with Haitman [27] self-purification of RSD is satisfying, water quality is generally adequate, excluding the upper section, whereas eutrophication and algal blooms are problematical. Occasionally oxygen deficiency occuring at dawn could be lead to perish of fishes. Diffuse pollution derived from holiday resorts should also not be neglected, furthermore canalization should be carried out. The water quality of RSD has not changed considerably between 1980-1990. Regarding some components, improvements, by others declining could be observed. Compared with the 50s and 60s, notable, favourable tendency became distinct in the case of water quality, however this tendency is not so obvious after 1980. Even so the river arm has been reached its loadability level.

Fekete et al. [21] discussed statistical methods for the analysis of water quality data with examples on the RSD. Trend analysis, autocorrelation, correlation analysis and 
factor analysis were added. According to the authors hydrometeorological relations, biological processes and effect of civilization should be considered when water quality is evaluated.

The Sewage treatment plant of South-Pest is the greatest source of pollution in the Danube arm, which gives $30 \%$ of the nutrient loads. However, it should be mentioned, that the nutrient content, introduced with Danube water is in itself enough to create eutrophic conditions [13]. The eutrophication process is limited by light and temperature, and not by nutrients. Reeds should be protected, the water quality of Danube should be improved and water loading should be provided from main arm to make the river status better, except that pollutants must be stopped [13]. A brief review of the protection of water quality is found in Clement's work [14].

Hollósy [30] performed trend analysis based on data collected between 1968-1993. After the author, wastewater loading is harmful mainly from the great $\mathrm{P}$ and $\mathrm{N}$ supply, which enhances eutrophication processes. Wastewaters can cause local problems, ammonium content could increase by 10 -folds $(10-15 \mathrm{mg} / \mathrm{l})$, while dissolved oxygen content decreases below 1-2 mg/l. These values are toxic for fishes and also several perditions have already been. Dissolved oxygen content is higher at the lower river stretch than at the upper section, because of the phytoplankton production. Highest values of total dissolved matter (average value: $321 \mathrm{mg} / \mathrm{l}$ ) is typical of the sampling site at Szigethalom. Based on data series of 25 years (1968-1993) water quality of RSD is improving, but further arrangements are needed [30].

Heavy oil pollution occured on RSD above the Gubacsi bridge in $11^{\text {th }}$ February 1994 [31]. A new method were developed for determining the time of pollution.

Water quality models were applied by Clement [15] on the example of RSD to describe the changes of water quality. According to Clement trophic status of RSD depends only on the meteorological and hydraulical conditions and not on nutrients. The first model has two variables: the algae phosphorus and the inorganic reactive phosphorus. Second model is constructed for eutrophication effects on dissolved oxygen, since in case of RSD the changes of the dissolved oxygen concentrations have a great importance (temporary depletion of dissolved oxygen level can lead to perishing of fish and mollusc).

Just et al. [35] dealt with comparing and co-ordinating the methods of water quality assessment used in Hungary and in Germany. In part of this study they carried out chemical, microbiological and faunistical examinations on the river Danube and on its side arm RSD. Five sampling sites were designated on RSD (after Kvassay sluice, Dunaharaszti, Majosháza, Ráckeve, Dömsöd). The evaluation of data was performed after the German standard method (DIN 38410) and after the method labored by Csányi (not published). The former method applies indicator organisms and saprobity index, latter ranged between 1-4 ( $S=1$ oligosaprobic and $S=4$ polysaprobic), taxa are weighted. During the survey, saprobity index ranged between 1,8-2,3, consequently betamesosaprobic state existed on the examined stretch of Danube. Csányi's ASPT (average score per taxon) method assignes scores (1-10) for each taxon based on susceptibility of taxa (mainly family) to pollution. After the Hungarian ASPT value researched waters proved to be more polluted, the above-mentioned methods can not be regarded as equal. Authors recommend using of saprobity system on the Danube. Several data were also presented on RSD. Nutrient and nitrate content were similar to the Danube, whereas higher values of ammonia and nitrite could be observed in connection with the stronger wastewater loading. Bacterial pollution was in the upper section up to Dunaharaszti 
high, higher than in the main arm, which was attributed to the sewage farm of South Pest.

Ráckeve-Soroksár Danube is alpha-beta-mesosaprobic in most cases $(\mathrm{S}=2,3-2,8)$, alpha-mesosaprobic state occurs rarely, mainly in winter period at the upper river section, when self-purification processes slow down on the account of the low water temperature. Beta-mesosaprobic state exists mostly at the lower stretch demonstrating the significant self-purification of the water. Based on data series of decades can be stated, that saprobiological state has not changed, only minor spatial and seasonal changes can be observed [90]. Oxygen supply is good, which can be originated mainly in the water movements and mixing, secondly in the oxygen produced by algae. Concentration of dissolved oxygen is prominent throughout the year, but loaded with nitrogen and phosphorus compounds, which occures chiefly in winter [86]. 86\% of total organic matter, $70 \%$ of total phosphorus and $75 \%$ of total nitrogen loading into RSD derive from Danube, whereas $96 \%$ of the total water body comes from the Danube at Kvassay sluice [87].

River bed sweeping is important in RSD, mainly in upper section, as silt loading from Danube settles here because of the low current velocity. Total mass of mud can be estimated around 4-17 million $\mathrm{m}^{3}$ [87]. Mud removed with this process, has a high nutrient content, so the decreased level of nutrients slows down algal blooms and eutrophication. On the other hand deeper bed does not favour algae since light conditions are not advantageous in the deeper regions. Previous conditions are also effectual for macrophytes. Sweeping has a negligible effect on zooplankton, whereas a positive effect may have on fishes [87].

Water quality of RSD has beeing measured since 1969 by KDV KF (Environmental Authority) with a two-week frequency as the part of National Sampling Scheme of Hungary. Examinations inlude both chemical and biological parameters, samples have been taken at four sampling sites: Kvassay sluice, Szigethalom, Ráckeve and Tass. Microbiological investigations have been performed more infrequently [90, 18].

Borsodi et al. [9] carried out bacterological study in RSD (at Taksony) and Lake Velencei. Bacteria have been isolated from Phragmites australis to use for molecular taxonomic studies. Authors drew attention to the important role of reeds in selfpurification processes and nutrient cyling in waters. On the biofilm of submerged reed surface, representatives of potentially new bacterial taxa adopted to the special environmental conditions were found besides the well-known Bacillus species. Submerged reed stems provide habitats for physiologically diverse groups of taxonomically closely related species [9].

\section{Phytoplankton}

The algal investigations of RSD started in the 20s [12] with diatoms, but the first detailed research dealing with algae was published in 1936 by Halász [28]. Ninekilometre-long river section was examined with 57 samples taken from 10 sampling sites between the years 1934-1935. Vegetation was divided into 3 groups in accordance with occurrence: plankton, benthos and reed. Low abundance of planktonic algae could be observed at Kvassay sluice, whereas much more algae occured at the Gubacsi bridge (mainly diatoms). Only diatoms were found during the ice covered period. In March appeared Oscillatoria, Pandorina and Eudorina taxa. Highest abundance occured in summer, especially in August and September, whereas in autumn algae species 
disappeared gradually in accordance with the descending water temperature. In winter only Pandorina, Eudorina and Oscillatoria were present. Reeds were characterized by Spirogyra, Zygnema, Desmidiacea. Altogether 82 species and varietas have been observed. Present author examined the diatoms of the Soroksár Danube in her next work [29], she felt it necessary to investigate this group because of its high abundance. She stated that diatoms show higher individual numbers at all times as compared to other phytoplankton elements. Several species occured permanently such as Melosira varians, Diatoma vulgare, Fragilaria crotonensis, Fragilaria capucina, Asterionella formosa, Synedra ulna, Synedra acus. Algal blooms occured in spring and autumn (the spring abundance is higher). Asterionella formosa dominated in spring, while Melosira granulata prevailed in summer and autumn.

Next phytoplankton survey was carried out just 30 years later. Palik [53] researched the algae living on concrete stuctures. Schiefner and Urbányi [64] investigated algae within the confines of a complex survey on the Soroksár Danube. They found 157 species of Bacillariophyta, 2 species of Xanthophyta, 5 species of Pyrrhophyta, 9 species of Euglenophyta, 21 species of Cyanophyta, 6 species of Crysophyta and 87 species of Chlorophyta. It is evident that diatoms are presented in the greatest number similarly to Halász's [28, 29] results.

Bothár and Kiss [11] investigated the phytoplankton and zooplankton of RSD. Phytoplankton samples were taken biweekly troughout the year 1983. They compared their results to the achievements of Schiefner and Urbányi [64] and concluded that the individual numbers are much greater in 1983 than were in 1970. The dominance of diatoms could also be observed, especially the Thalassiosiraceae should be mentioned. Frequent species with high abundance were also Cyclotella sp., Sceletonema potamos, Stephanodiscus hantzschii and S. tenuis. During the winter period algae occured still in high abundance in contrast to Halász's [28] and Schiefner and Urbányi's [64] works. It means that the individual numbers in December (51 million ind./1) were greater than the maximum abundance (46 million ind./1) during the whole survey period observed by Schiefner and Urbányi [64]. Trophic state of RSD was found eu-polytrophic at Ráckeve throughout the year.

According to Kiss [40] the diatom family Thalassiosiraceae has a prominent role in algal blooms. Occurrence and morphological descriptions of this family are provided, extended also to the Soroksár Danube between Dunaharaszti and Ráckeve. Because of the small size of these species using of electron microscope is considered important.

Kiss and Genkal [41] examined phytoplankton blooms in river Danube and in its side-arm. Authors drew the attention to the lack of data on winter populations, because phytoplankton of large eutrophic rivers can be significant even in winter and can be an important factor in primary production. Samples were taken at Dunaharaszti and Ráckeve biweekly or at least monthly. The side-arm was often frozen and the ice was often $15-20 \mathrm{~cm}$ thick and was covered with snow in many cases. However ice and snow found not to be limiting factors in the development of blooms. Important factors regulating winter Centrales blooms were nutrient supply, slow water speed and high transparency. During high water periods the current speed is high and the phytoplankton composition is similar to that of the Danube, whereas during low water periods the current speed is low and phytoplankton composition and density change considerably. Characteristic species of the winter diatom blooms proved to be Stephanodiscus hantzschii and S. minutus, highest trophic values occured at Ráckeve. 
Barreto et al. [2] conducted phytoplankton survey on Soroksár Danube covered with ice, in January 1997. They collected samples from the boundary of DunaharasztiTaksony. Abundance was much greater $(11680 \mathrm{ind} . / \mathrm{ml})$ than found in the Danube, which can be originated in the high nutrient supply and transparency as well as in the low amount of suspended matter. Phytoplankton composition developed as the follows: Euglenophyta 1, Chrysophyceae 9, Bacillariophyceae 18, Cryptophyta 4, Chlorophyta 9. According to the writers, Bacteria adhered to the diatoms play an important role in the self-purification of the river.

Just et al. [35] took phytoplankton samples from the Danube and its side arm. Five locations (after Kvassay sluice, Dunaharaszti, Majosháza, Ráckeve, Dömsöd) of RSD were concerned in this survey conducted in 1996. Chlorophyll $a$ content was lower in the side arm than in the main arm. A possible explanation for this was given by the writers, namely higher turbidity existed in RSD. The chlorophyll content remained relative constant along the side arm.

Szabó et al. [69] studied periphyton and phytoplankton on RSD. Samples were taken at Taksony in 1996-1997, and at Ráckeve in 1998-1999. Based on the chlorophyll $a$ content of the phytoplankton the upper part of the Soroksár Danube at Taksony was oligotrophic in November and July, mesotrophic in January and eutrophic in April. The side arm was eutrophic in April and July, oligotrophic in November and January at Ráckeve. The maximum abundance was $28560 \mathrm{ind} . / \mathrm{ml}$ at Taksony and $37340 \mathrm{ind} . / \mathrm{ml}$ at Ráckeve. There was a correlation between periphyton abundance on old and green reed stems that is a higher abundance on the old than the green reed stems was observed. Eunotia arcus showed considerable abundance at Ráckeve, which provides a new record for the side arm. This species prefers low nutrient levels, accordingly its occurrence is strange. The authors compared their results with Halász's [28, 29] results and pointed out that while diatoms were present in the highest species number in both cases, Halász found more Zygnematophyceae while they found more Chlorophyceae species. Above-mentioned phenomenon was interpreted by the lower concentration of nutrients and the lower trophic level existed in the 1930s. Additional comparison was given, that is Halász found more oligotrophic diatoms, whereas present authors found many eutrophic-tolerant species among diatoms. It is in accord with the declining water quality.

Seasonal dynamics patterns and other establishments were summarized in the year 2000 [90]. During winter months phytoplankton production is low, other organisms like bacteria, Ciliata, Flagellata can occur in high abundance, however algal blooms can also occur. In spring, with the increasing water temperature rapid algal production can evolve, and under the dominance of Centrales species eutrophic, eu-polytrophic state can be realized, which is composed by few species. Primary production declined at the end of May, phytoplankton composition changes during the summer, green algae occur in high abundance and species number. In autumn, algal abundance increases again with the dominance of Centrales species. By flood algal production decreased because of the suspended matter and lower transparency. Much oft the suspended matter settles at the upper part of RSD, so lower does not effect the phytoplankton considerably. That could be the reason for the higher algal abundance at the lower river section (at Ráckeve and Tass). Further data to the knowledge of algae can be found in other works [1, 42]. 


\section{Zooplankton}

In 1956 the articel of Berinkey and Farkas [5] was published, which expressly deals with plankton Crustaceans, respectively with the nutrition supply disposable for fishes. Notwithstanding that the surveys were carried out at a stretch of 2 kilometres (river $\mathrm{km}$ 20-22) and 3 sampling sites were designated, it counts as a fresh ground for RSD research. Present authors described 14 Cladocera species and stated that the river arm as a considerably eutrophicated water deserves top interest.

Berczik [6] reviewed the aquatic fauna of the Hungarian stretch of the Danube on the grounds of data from literature. The Soroksár Danube arm was also mentioned, but no checklist was presented for RSD, simply higher taxa were demonstrated.

Schiefner and Urbányi [64] performed also plankton surveys under complex hygiene examination of the river arm. They pointed out that the abundance of plankton organisms increased gradually from Pesterzsébet up to Tass, highest individual number was found in May. 17 Rotatoria species were identified, the water quality was betamesosaprobic based on saprobiological evaluation.

Bothár in her work, published in 1973 [10], analysed the zooplankton samples taken once in a fortnight, for one year, at 3 sampling sites (Soroksár, Dunaharaszti, Ráckeve). At each sampling site occured two peaks: end of May-early June respectively end of August-early September. The author set out that the upper river stretch (Dunaharaszti and Soroksár) has a similar fauna and low individual numbers as compared to the lower stretch, where more species occur and with higher abundance (abundance increased by 30-fold). Previous difference was explained by the pollution of the upper river stretch. The temporal variation of the copepod and cladoceran community was also presented. According to Bothár quantitative and qualitative differences exist among copepod and cladoceran standing stock. During the survey 38 Cladocera and 14 Copepoda species were recorded.

Gulyás and Tyahun [23] similarly investigated the Crustacea plankton of RSD, samplings conducted between May and October 1970 from four sites (Szigethalom, Ráckeve, Dömsöd, Tass). The fauna of reedgrass vegetation was examined both quantitatively and qualitatively, additionally saprobity was estimated. However the authors came to the conclusion that the saprobiological evaluation based on crustacean led to unreal notion in the RSD (oligo-beta-mesosaprobic state). 28 Cladocera, 12 Copepoda and 2 Ostracoda species were identified from samples. In accord with the results of Bothár [10] both the abundance and species number increased around the lower river stretch. In the upper river stretch by Szigethalom, which is more polluted and muddy, are living common species with high level of adaptability. The quantitative and qualitative change of the Entomostraca fauna was identical along the whole section of the river arm. Copepods occur first in the spring, their abundance decreases in summer and increases in autumn again. Contrarily cladocerans peaked in summer and autumn.

Győrbíró [26] dealt partly with cladocerans in his diploma work. Four sampling sites (Soroksár, Szigethalom, Ráckeve, Makád) were included in this research conducted between July and September. Results were compared to Berinkey-Farkas's [5] work. According to Győrbíró the abundance of plankton collected at Soroksár and Szigethalom were constantly decreasing during the survey, while at Ráckeve at first moderate then sharp increasing was followed by a sharp decreasing. It is worth mentioning the low number of Cladocera found by the writer. 
Tyahun $[72,73]$ announced data of Copepoda, Cladocera and Ostracoda from four locations (Szigethalom, Ráckeve, Dömsöd, Tass). In addition to the checklist, seasonal dynamics was also presented, namely copepods are among the first organisms inhabiting the reedgrass, they are characterized by spring and autumn peaks, cladocerans appear later with an abundance maximum in autumn, ostracods could reach the abundance of the order of one hundred thousand in August and September.

Bothár and Kiss [11] conducted phyto-and zooplankton investigations bimonthly at Ráckeve in 1983. They found less species than Bothár in 1970-71, and no other species turned up. The formerly dominant euplanktonic Bosmina longirostris occured rarely just as other Cladocera species characteristic previously. Summarized the results they came to the conclusion that the Ráckeve-Soroksár Danube arm has reached the eu-polytrophic state as compared to the meso-eutrophic, eutrophic state existing in 1970-71.

Gulyás [24] examined the Rotatoria and Crustacea plankton of RSD and the main arm for one year. Rotifers were presented in the greatest abundance and also most species occured among Rotatoria. In the initial stretch of the river arm biomass and species composition were similar to the main branch, whereas 20-25 kilometres down increased the biomass notably. In the lower stretch biomass value characteristic for polytrophic stagnant water was measured.

Just et al. [35] dealt with comparing and co-ordinating the methods of water quality assessment used in Hungary and in Germany. In part of this study they carried out chemical, microbiological and faunistical examinations on the river Danube and on its side arm RSD. Five sampling sites were designated on RSD (after Kvassay sluice, Dunaharaszti, Majosháza, Ráckeve, Dömsöd). Greatest zooplankton biomass was found at Ráckeve in June. Most zooplankton species occured among rotifers, 13 species turned up only in the river arm. Difference in species composition between the main brach and branch was interpreted by the different rate of flow (the lower stretch of the RSD has a character of stagnant water).

The qualitative and quantitative changes of Rotatoria and Crustacea plankton in the river Danube was published by Gulyás [25]. In this survey took part 10 researchers from different nations in order to examine the section of Danube between Neu-Ulm and Tulcea incorporating 2581 kilometres. Examinations trended not only to chemical water quality evaluation, but also following the ecological state of the water with attention, in tune with the Water Framework Directive. In the RSD high abundance and low number of species were found during the survey. Rotatoria and Crustacea species characteristic of polytrophic water bodies were presented. Present survey was also published as a summary report „Joint Danube Survey” [48].

\section{Macroinvertebrates}

Tyahun $[72,73]$ described the population dynamics of the mesofauna of RSD. These were the first publications concerning makroinvertebrates in RSD within the confines of a comprehensive approach, giving ecological explanations. Previously were simply fauna descriptions available considering only several taxa. The author appointed that species composition and change in abundance are mainly regulated by spatial inhomogenity, pondweed stand play second fiddle. In the lower river stretch more species were found that was interpreted by the pollution of the upper stretch similarly to Bothár [10]. The dominance of Chironomidae and Oligochaeta could be observed. 123 
new species were described to the fauna of RSD, 47 species proved new to the whole section of the river Danube.

Just et al. [35] investigated the macrozoobenthos in the framework of the abovementioned survey, 25 taxa were only found in RSD thus no occurrence in the main branch of the Danube was observed. The distribution of species among taxa in RSD was similar to the pattern observed in the main branch. The former was characterized by the presence of Erpobdella octoculata and the dominance of Chironomidae and Oligochaeta similarly to Tyahun's $[72,73]$ results. The number of taxa increased southwards.

Csörgits and Hufnagel [17] analysed similarity patterns of Heteroptera communities in the Danube. They illustrated Heteroptera communities of several habitats (also RSD) based on a database of Heteroptera. The similarity of RSD to other freshwaters based on their aquatic bug fauna can be observed.

Csányi et al. [16] summarized the results of three different surveys. From 1995 to 2001 they conducted examinations at 9 locations with sampling sites changing yearly: in the years 1995, 1996, 1998 and 2001 sampling was performed by Kvassay sluice, in 1995, 1996 and 1998 at Dömsöd, however at the backwater by Szigetcsép only in 1998. The taxa of the macroinvertebrate assembly found by the writers, are almost animals with high adaptability, characteristic of stream waters with low flow rate and with high nutrient content. Molluscs proved to be dominant, rheophyl taxa occured only occasionally. Authors drew attention to the dead arms, swamps and fens which could support numerous species new to the fauna of RSD.

Kontschán et al. [43] aimed to giving a key to identify Amphipoda species living in Hungary, concerning 12 species. The Ráckeve-Soroksár Danube arm was not mentioned, only a general description was presented of Danube living amphipods.

Bódis and Oertel [7] examined the mussels of the Hungarian stretch of the Danube included also RSD with four locations. Both faunistical descriptions and ecological conclusions were set out. From the 19 species turned up during the survey, 11 species occured also in RSD. Multivariate analysis was used to examine the connection between mussels and environmental factors. Most species favoured low flow rate.

Finally, we give the faunistical publications concerning RSD. Woynarovics [82] gave an account of the first observation of Limnomysis benedeni (in 1950) in RSD. Berczik [6] presented a short review of the macroinvertebrate fauna, nevertheless no checklist was added refer to the RSD. Tyahun [71] described the water mite (Hydracarina) fauna of RSD (samples processed from four sampling sites) as well as a new species to science (Arrenurus dudichi). However later previous species proved to be identical with Arrenurus furciger.

Additional data to the macroinvertebrate fauna of RSD are presented in the following works: on Heteroptera Hufnagel [34], on Trichoptera Ujhelyi [74, 75], on Mollusca Richnowsky [63], Pintér et al. [57], Pintér and Szigethy [58, 59], Varga and Csányi [78], Varga et al. [79], Bódis and Oertel [7], on Odonata Steinmann [67], Benedek [4], on Chironomida Móra and Dévai [51], on Ephemeroptera Kovács [45], on Decapoda Kovács et al. [46] reported data of occurrences.

\section{Macrophytes, shoreline vegetation}

The wood types of Hungarian floodplain area of the Danube can be found in Kárpáti's work [37]. 
The occurrence of Urtica kiovensis in the Danube floodplain has been reported in Kárpáti's study [38]. Fieldwork was carried out in the year 1961. The facies of Urtica kiovensis was spread among the bridge at Szigethalom and Majosháza in the coastal zone of 10-30 m, up 70-120 cm water depth. Phragmition and Magnocaricion web constituted swamps, where Urtica kiovensis was mostly widespread. Kárpáti pointed out, that the constant water level and low current velocity made for this species possible to colonize the area.

Kárpáti [39] reviewed the vegetation of Danube concerning also RSD. Six associations are discussed concerning RSD: Lemno-Utricularietum, Wolffietum arrhizae, Hydrochari-Stratiotetum, Myriophyllo-Potametum, Nymphaeetum albo-luteae and Trapetum natansis. Wolffietum arrhizae should be emphasized since it occurs very rarely in Hungary. Characteristic species of previous association are Hydrocharis morsus-ranae, Spirodela polyrrhiza, Riccia fluitans, Lemna trisulca, Lemna minor, Wolffia arrhiza and Ceratophyllum demersum. Greatest magnitude has on RSD Lemnetosum trisulcae with the species Lemna minor and Lemna trisulca. Further species which are worth mentioning: Utricularia vulgaris, Myriophyllum spicatum, Nymphaea alba, Nymphoides peltata, Potamogeton lucens, Nuphar luteum, Trapa natans, Stratiotes aloides.

Reedgrass borders the riverside almost along the whole river section, especially at shallow parts and dead arms. Most-significant species are Lemna minor, Spirodela polyrrhiza, Utricularia minor, Utricularia vulgaris, Trapa natans, Hydrocharis morsusranae. More diverse are the associations of reedgrass rooted in water with the species Ceratophyllum demersum, Myriophyllum spicatum, Myriophyllum verticillatum, Potamogeton pectinatus, Potamogeton perfoliatus, Elodea canadensis, Polygonum amphibium, Chara sp.. More infrequent are Nuphar luteum, Nymphoides peltata and Nymphaea alba [90]. Reedgrass plays important role in self-purification processes, as well as it supports nutriment and resource for fishes and macroinvertebrates. However it should be mentioned that native vegetation has been disappeared in several section. Numerous holiday resorts have been built at the expense of wildlife. The shoreline is surrounded with reed (Phragmites australis) and bulrush (Typha angustifolia) in most sites [90], they have importance by straining pollutants loading from shore.

Among the associations on RSD, swamps deserve greatest attention, namely they count as rareness all over Europe. These growths have peat soil and are constituted from Phragmites australis, Typha latifolia, Typha angustifolia, Glyceria maxima, Schoenoplectus lacustris Sphagnum spp. and other plants. Orchids like Dactylorhiza incarnata and Epipactis palustris and infrequent moss species (Sphagnum recurvum, Sphagnum squarrosum) are also worth mentioning. Swamps play an important role in water quality, as they take up nutrients from water body and store these as peat for geological periods. This processes set back eutrophication because less nutrients are available, nevertheless they adsorb toxic metals and organic pollutants [90]. Most important swamps can be found at Dunavarsány, Szigetcsép, Szigetszentmiklós and Taksony [88]. 


\section{Vertebrates}

\section{Presentation of the fishing-fish faunistic examination}

Beside its role in the industry and transportation RSD is a remarkable fishing area. Consequently all scientific studies of the fish fauna in the RSD have examined the arm in respect of fish production.

In the "prehistoric" time of the RSD fisherman-tenants hired the water and they got other fisherman (paid by fish) to fish in the area. The tenancy was fixed for a certain period and the tenant's only motivation was to make profit. So there was no investment at all. In the 1930s fishing associations took over the water tenancy and from that time the RSD Arm has been a fishing area. Since 1945 the Ráckeve-Soroksár Danube Arm Fishing Associations at Ráckeve has owned the RSD. It is important to mention that there was selective fishing till 1969. In the beginning carnivorous fishes were also caught. Each year 90-120 tons of fishes were caught in the RSD between 1947 and 1950. In the history of the RSD there was a tragic event in 1953. Owing to phenol pollution in winter $90 \%$ of the fish population died out. (The Fishery at Makád was created to make up for the loss) Catchings began to grow again till the winter 1962-63 when another disaster struck: approximately 140 tons of fishes died out. They managed to make up for the loss by breeding and the quantity of catching was 60-70 tons per year. Placing pike-fish nests (1000-1500 nests belonged to the Ráckeve-Soroksár Danube Arm Fishing Associations and 250 nests were purchased was remarkable development. From 1949 they were breeding Largemouth bass for several years. In 196240,000 Eels and in $1970309 \mathrm{~kg}$ of Tenches were introduced - as an experiment in the RSD. Nothing proves the importance of the RSD better than the fact that the RSD Fishing Association has 24,000 members and it is visited by 15-16,000 guest fishermen every year. With regard to the figures above we can see that the natural breeding - which is rather insignificant because of the present conditions of the bank considering the great number of the fishermen is insufficient to support the fish population. So new and more fish population is required. The fish production is based on the Fishery at Makád where there are 6 pounds in an area of 91 acres and 200-220 tons of fishes can be produced every year. Most of the fishes are Carp but there are herbivorous and carnivorous species as well. In the last few years the above activity has been done according to new views. Before the 1990s only the quantity was taken into consideration. Now new aspects dominate: as the RSD is natural water we find fishery conditions created by not human but a complex ecological system. The RSD Fishing Association works based upon this fact and pays attention to the natural feautures. The association always does research and makes survey before planning their activity [95, 96]

The number of species - that has been described so far - is 54 . Ten of them is very rare or is an "occasional guest" e.g. Brown trout, Rainbow trout, Goldside loach, Razorfish, Burbot. Increase in some species can be observed e.g. Mudminnow. Near the two sluices we can see mainly species that like stream (reophyl species). Eutrophisation is the reason for the dramatic increase in worthless, white fishes and for the decrease in more precious fishes such as Pike perch.

In the following we are giving a summary of the articles associated with fishing and fish fauna in the RSD.

Berinkey and Farkas published the first study of the RSD in 1953 [5]. The objective of their examination was the nutrient that was available for fishes. They analysed the 
gastric contents of the fishes so that they could determine which of the nutrients the Carp and the Carp bream chose. The authors found out that the nutrients of the two species above mainly came from the animals in the bank zone and the benthos. Tubifex, Chironomus and Entomostraca in the benthos were the most important nutrients of both species. So the Carp bream is the rival of the Carp in the nutrition. Only few pelagic, zooplanktonic organism were found - on average 8/50 liters of water per year. Unfortunately the authors did not show the zooplanktonic species in the samples of surface water so comparison can not be carried out based on this study. Another problem is that they examined the gastric contents of few species and in a small period of the year. So it is difficult to determine the nutrition of the fishes all around the year, especially if we take the seasonal quantity changes of the zooplanktonic and other organism into consideration.

In 1956 Woynarovich published his article [83], "What is happening to the RSD Arm?" This article is a short survey of the conditions and problems at that time in the RSD. The author says that a fish breeding association managed to make up for the loss that had occurred in spring 1954, when lots of fishes died out and owing to this disaster 3000 acres of water area destroyed. The article mentions a problem - that was current at that time - that is the Danube from below at the Tass sluice gate flooded the RSD. In such cases fishes normally move against the stream and when the water is falling, they swim with the water. But at the time of the flood fishes hibernated - were in torpor and inactive - so they were in danger of drifting with the stream. As the flood was stopped by putting stones to the sluice there was no significant loss according to the writer of the article. But he mentions that the number of bream species and other undesirable fishes that the stream removed from their hibernaculum and drifted away - could increase.

In 1968 Horváth published his study [33] dealing with the question: How to make up for the loss that occurred during the previous decade? The article states that from 1964 each fisherman was allowed to catch 4 Pike-perches per day and had to keep them without limitation on the sizes of the fish. According to the author there was a remarkable increase in the number of carnivorous fishes but carp introduction had to be discussed. The author mentions $150 \mathrm{~kg}$ of fish yield per acre so according to his calculations 450,000 kg / 3000 cadastral acres per year is the fishyield (consisting of different fishes) regardless of any loss. The author thinks the half of the yield must be Carp. He adds that introduction of 225-230,000 progeny per year would be needed as practically there is no natural breeding owing to the changes of water level.

The same author studied the composition of the fish fauna [32]. In his opinion Largemouth bass - that was introduced in the ' $50 \mathrm{~s}$ - would absolutely needed as it is the killer of undesirable fishes. The author describes the Prussian carp as a relatively new species that came into the RSD through pumps from Dózsa agricultural co-operative. It is important to point out that on Szigethalom island the writer of the article caught Mudminnow, Weather fish and Tubenose goby by net. According to him the Mudminnow is not so rare as it is reflected in the scientific literature.

In 1977 Ribiánszky published his study on the fishfarming features of the RSD Arm [62]. On the basis of 12 years' facts - beginning with the year of 1963 - the author studied the fish production characteristics of the RSD. According to the article presenting several figures, charts - during 10-12 years fish production became three times and a half bigger than it had been, the catching of Carp went up by $50 \%$ and the stock of Pike-perch quadruplicated. The author thinks that that the growing number of Wels is worrying. In his opinion the reason for it is that the bigger the Wels is the more 
and bigger fish is needed "on the menu". On the basis of the No. 3 chart during 12 years the catchings per fisherman went up to $34.42 \mathrm{~kg}$ from $10.05 \mathrm{~kg}$. Based on these figures the author supposes that the yield in natural water also increased. He expects $500 \mathrm{~kg} /$ acre natural yield. (Author Horváth in his study - mentioned above - expected $260 \mathrm{~kg} /$ acre). According to Ribiánszky the ideal composition of carnivorous fishes is the following: $50 \%$ of Pike-perch, $10 \%$ of Pike, $30 \%$ of Asp, $10 \%$ of Wels. The author explains that the number of fishermen increased dramatically and meeting higher requirements is unavoidable but it is guaranteed by the water natural supporting character. The Fishery at Makád needs to be improved though.

Veszprémi's article $[80,81]$ is based on a more than 200 page study. It says that the fishing - biological examination of the RSD was being carried on between the sluices Kvassay and Tass from April 1974 to March 1975. Water samples were taken in 12 regions every month. They examined the water pollution, the supply of mineral substance and organic compounds, the quantity and quality composition of phyto- and zooplankton organism, the supply of oxygen. They examined the mud pollution and the quantity of the living organism in the mud. The article reveals the results of these examinations in details. By giving a summary the article states that the results are mainly reassuring. During the 25 years before the article the water quality in the RSD had improved a lot as regards the fish physiology. The reason for it is that the toxic pollution came to an end. The examinations show that the phyto- and zooplankton quantity is twice as much than it was in the 1950's. The same applies to the quantity of the worms and insect larvae living at the bottom and in the mud. It is mentioned as a fact that because of the decreased but continuous pollution the upper third of the RSD has poorer quality than the lower water area.

Papp and Fábián [55] compare the reservoirs at Pátka and Fehérvárcsurgó, the backwaters at Kákafok, Fadd - Dombori and Alcsi island, the RSD, the lakes at Délegyháza and the Quarry lakes at Csepel. The main objective of this comparitive study was to examine the interaction of water quality, fish introduction and catching results. According to this examination the water quality is unstable and at some places it is unfavourable. During a few years previously the examination the RSD Fishing Association introduced 180-200 tons of fishes and in the authors' opinion it was really great sacrifice. The authors think that a survey of the fish fauna quantity and composition would be needed. The growing pace of different species should be studied as well.

In 1967 Rácz published the request according to which they had begun fish marking as an experiment [61]. The percentage of the marked fishes was the following: $40 \%$ Carp, 30\% carnivorous - mainly Pike, Pike-perch and the remaining 30\% consisted of different species mainly bream. Beside growing they also planned to examine whether fish groups develop in fresh water or not. They planned to mark 3,000 fishes.

As an extension of the previous article Fábián [20] announces the achieved results. In 1968 the catchings of the marked fishes was $11,6 \%$, in 1969 it was 7,7\%. The author believes that when fixing the most profitable average weight at the introduction, the monthly increase in weight - till the fish reaches the desired size - and the rate of the loss of the breeding animals -that have different weight- should be taken into consideration. Based on the catching results the author says that the introduction of $20-$ 30 decagramme two- summer progeny is the most ideal. He concludes from the approximately $68-78$ decagramme increase in weight per year, that contrary to the introduction of $70-80$ tons at that time, the introduction could be increased to $100-$ 
120 tons without the danger of decrease in weight. The author believes that the facts of 2 years are not enough to come to the final conclusion.

Fish breeding in Fishery at Makád was presented in Fürész's work [22]. Between the years 1974 and 1981 data of growth and introducing were given.

In 2003 Szent István University and the RSD Arm Fishing Association took samples upon the Association's call "Opportunities of the Carp Natural Breeding in the RSD" They carried on the examination by electronic fishing machine at Majosháza, at Szigetszentmárton, at Raffás island, in the backwater at Dömsöd, on two spots at Szigetcsép and between the $5-6$ river kilometre mark. They examined the length and weight, analysed scale samples in laboratory. They showed 24 species in the RSD. Two species, Tubenose goby and Bitterling are protected by nature conservation. Eight species: Pike, Asp, Carp, Grass Carp, Wels, Pike-perch, Largemouth bass, Volga pikeperch were protected by size limitation. Beside protection they classified the species according to danger, ecology, life history, reproductive strategy, population in the habitat. The objective of the examination was mainly to survey the natural breeding opportunities not a comprehensive fauna study [92].

Samples were not taken at the upper section of the RSD. Consequently the described species are only for information. Nevertheless it has been the most remarkable examination in the recent years.

\section{Amphibia, Reptilia}

Besides fishes, sources on vertebrates in RSD is very scarce. Herpetological atlas of Hungary [60] contains the species living in this river arm and also gives further information of the species in question. The data base of this atlas contains altogether 16627 data distributed among $102010 \mathrm{~km}$ x $10 \mathrm{~km}$ UTM squares. Nine methods were used for detecting amphibian and reptile species. For the species see Appendix. RSD deserves increased attention because of the reptiles and amphibians living and reproducing here [90]. We have not found any publications besides the abovementioned works.

\section{Illustrating the publications}

Fig. 3. shows the investigations carried out on RSD in temporal aspect. Only publications were included, reports were not considered. Number of studies has been increased up to the $70 \mathrm{~s}$, then was a small decline in the $80 \mathrm{~s}$. The earliest studies were algal investigations, whereas in the 60-70s most important fish, zooplankton and macroinvertebrates studies were published. In the 90-00s mainly water chemistry, phytoplankton and macroinvertebrates were favoured.

Looking at Fig. 4. it is conspicuous that macroinvertebrates have main interest, but it should be mentioned, that many of these macroinvertebrate surveys are only faunistic publications with data of occurrence also refer to other waters. Interestingly phytoplankton and zooplankton studies contribute $15-15 \%$, fishes have also great magnitude in investigations. 


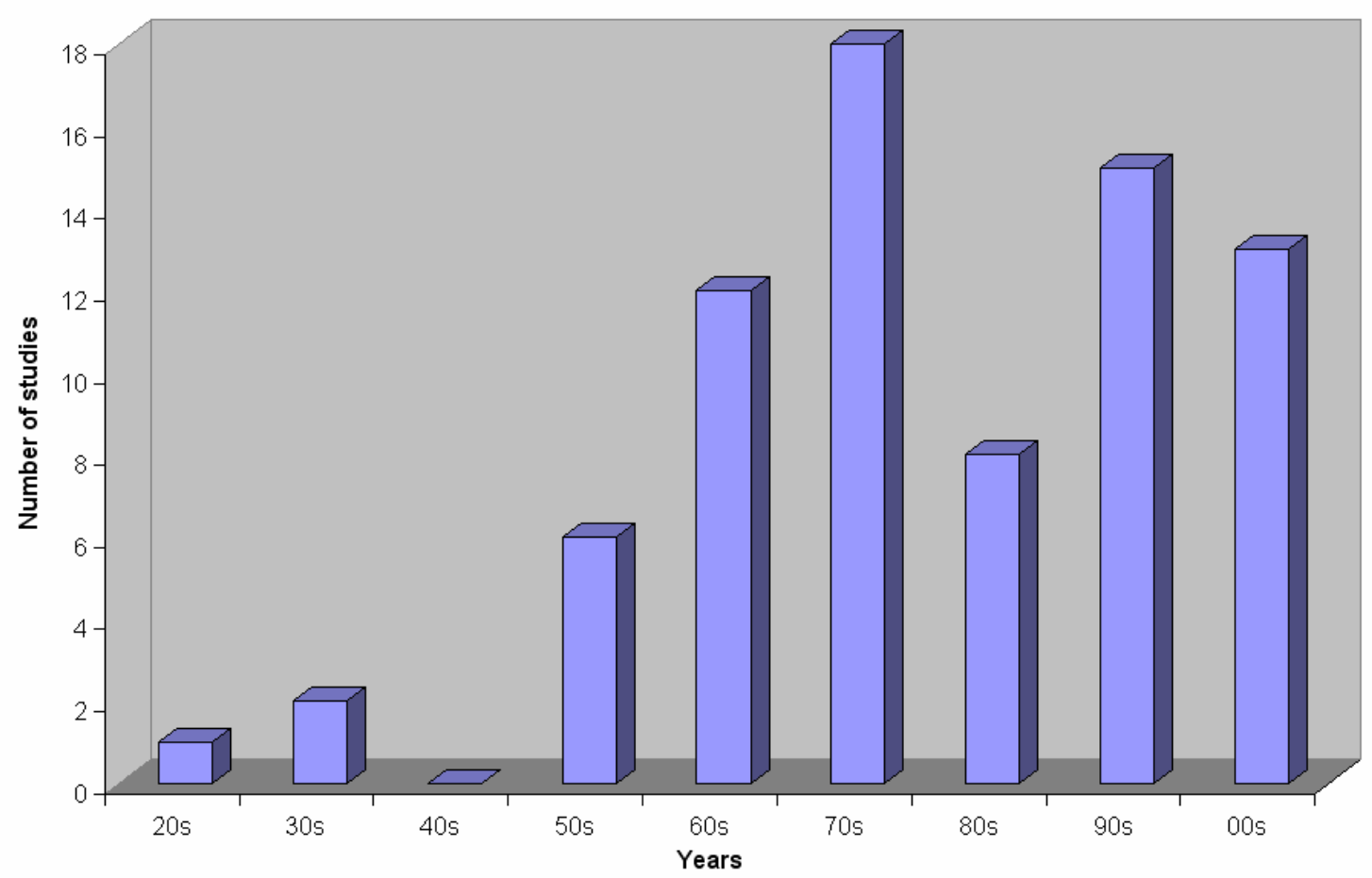

Figure 2. Distribution of studies carried out in RSD among decades.

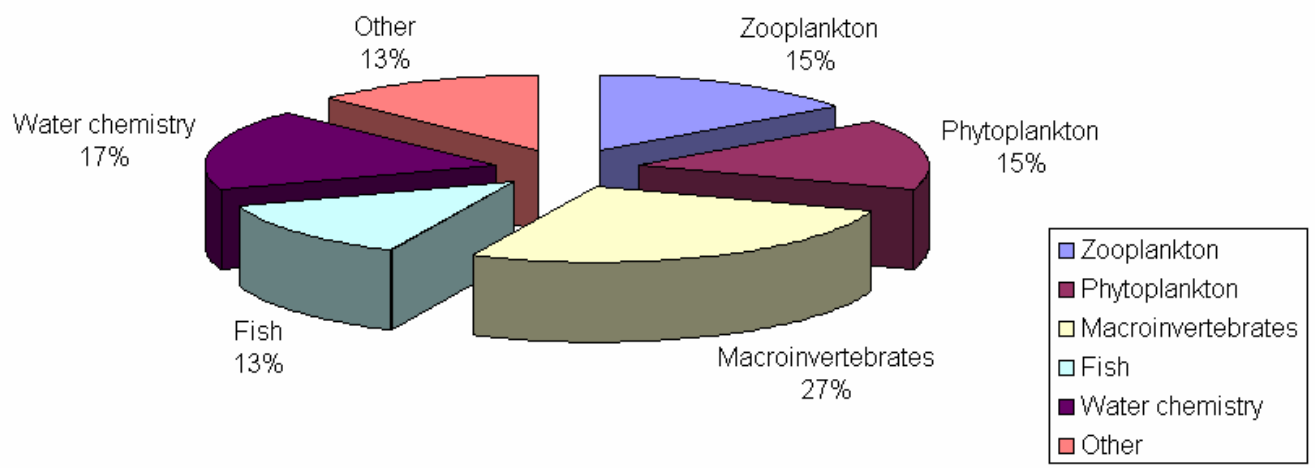

Figure 3. Distribution of objects among studies carried out in RSD.

\section{Summary and future tasks}

We have seen the RSD in many aspects, which from water quality is one of the most crucial. The saprobic state of RSD proved to be beta-mesosaprobic and alpha-beta mesosaprobic in most cases, alpha-mesosaprobic state occurs rarely. However spatial differences existed, namely the upper section is characterized by higher pollution due to 
the wastewater loading. Based on bacterological pollution only the lower section is susceptible for bathing, but not recommended at all times. The upper section is polluted, the effects of wastewaters are sensible unequivocally, however as from the lower stretch this effect ceased. Self-purification processes play an important role in the water quality. Many problems should be taken into consideration, such as eutrophication, occasional oxygen depletion, algal blooms, wastewater overloading, bacterological pollution, diffuse pollution, siltation. Long-term change in the water quality is not easy to interpret, but has been improving since the $70 \mathrm{~s}$, notwithstanding the situation is not so simple and requires attention.

Reeds and swamps should be protected as they play an important role in selfpurification processes, whereas swamps are worthy for additional research as they are speciality of RSD.

Algal investigations pointed out that not only spring and autumn, but also winter peaks can occur and the abundance can reach the number of 50 million ind./litre. Diatoms proved to be the most important group with highest abundance. Current velocity, water level fluctuation, nutrient content and transparency found to be crucial factors affecting algal production. Trophic state was estimated in some cases (from oligotrophic to eu-polytrophic states have been observed).

Notwithstanding that more publications have been published concerning macroinvertebrates than zooplankton, the latter has been researched more detailed. The reason for this is that zooplankton surveys have been begun earlier, on the other hand many macroinvertebrate investigations have been focused on faunistic description. Several taxa of macroinvertebrates have been researched purly in RSD, expectedly new species will be described.

More research are needed from ecological point of view, spatial and temporal changes should be taken into consideration and evaluated, nevertheless comparisons should be handled watchfully. Furthermore the modelling approach lacks. Wastewater loading, diffuse pollutants should be kept in check and continuous measuring of chemical and biological components of water quality are needed. RSD deserves more attention not only for the sake of its location, recreation possibilities, manageable water level, fishery, but for the specific habitat and reach fauna and flora.

Acknowledgements. We wish to express our gratitude to the following persons for their help: Pál Gulyás, Szabolcs Tyahun, János Nosek, Ákos Ucherkovich, Arnold Móra, Tihamér Kiss Keve, Adrienne Clement, Judit Makk, Árpád Berczik, Gábor Guti, Miklós Puky, Nándor Oertel, Katalin Zsuga. We are grateful to KDV-KÖVIZIG, VITUKI and the Hungarian Danube Research Station.

\section{REFERENCES}

[1] Ács, É., Szabó, K., Pápista, É., Kiss, K. T., Barreto, S., Makk, J. (2000): Etude des algues épiphytes et planctoniques D'un bras du Danube (Soroksári-Duna, Hongrie). Cryptogamie, Algologie - 21:254-255.

[2] Barreto, S., Ács, É., Kiss, K. T., Makk, J., (1998): Jég alatti algavizsgálatok a SoroksáriDunán. - Hidrológiai Közlöny 78: 300-302.

[3] Bartholy, J., Weidinger, T. (1997): Magyarország éghajlati képe. — In: Karátson Dávid (ed.): Magyarország földje - Kitekintéssel a Kárpát-medence egészére. Magyar Könyvklub, Budapest, pp. 240-241. 
[4] Benedek, P. (1966): Adatok Magyarország szitakötőfaunájához (Odonata). — Folia Entomologica Hungarica 2: 501-518.

[5] Berinkey, L., Farkas, H. (1956): Haltáplálék vizsgálatok a Soroksári-Dunaágban. Állattani Közlemények 45: 45-58.

[6] Berczik, Á. (1966): Über die Wasserfauna im Anland des ungarischen Donauabschnittes. (Danubialia Hungarica, XXXV.) Opuscula Zoologica Budapest 6: 79-91.

[7] Bódis, E., Oertel, N. (2005): Faunisztikai és ökológiai vizsgálatok a magyarországi Dunaszakasz kagylóin. - Állattani Közlemények 90:45-61.

[8] Bognár, M. (1990): A Ráckevei-(Soroksári-) Duna története és nagy mütárgyai. Hidrológiai Tájékoztató 30: 22-23.

[9] Borsodi, A., Makk, J., Rusznyák, A., Vajna, B., Taba, Gy., Márialigeti, K. (2007): Phenotypic characterization and molecular taxonomic studies on Bacillus and related isolates from Phragmites australis periphyton. - Aquatic Botany 86: 243-252.

[10] Bothár, A.(1973): Crustacea-Planktonuntersuchungen im Donauarm von Soroksár. Annales Universitas Scientiarum Budapestinensis de Rolando Eötvös Nominatae (Danubialia Hungarica LXV.) 129-144.

[11] Bothár, A., Kiss, K. T. (1984): Phyto-und zooplankton Untersuchungen im Donauarm Ráckeve. - 24. Arbeitstagung der IAD. Szentendre. Ungarn. II. 85-88.

[12] Cholnoky, B. J. (1922): Adatok Budapest Bacillarieainak elterjedése ismeretéhez. Botanikai Közlemények 20: 66-79.

[13] Clement, A. (1994): Can it still be saved? Survey of the Ráckeve (Soroksár) Danube. Vízmü Panoráma 2: 30-32.

[14] Clement, A. (1994): Pestszentimre szennyvíz-elhelyezésének szerepe a Ráckevei-Soroksári Dunaág vízminőség-védelmében. - Hidrológiai Tájékoztató 34: 9-10.

[15] Clement, A. (1996): Application of eutrophication models on Hungarian examples: Ráckeve Danube Branch and the Small Balaton Reservoir. - Acta biologica Debrecinasupplementum oecologica hungarica 7: 191-204.

[16] Csányi, B., Juhász, P., Tyahun, Sz. (2002): A Ráckevei-Soroksári-Duna makroszkópikus gerincteleinek vizsgálata. — Vízügyi Közlemények 84: 173-193.

[17] Csörgits, G., Hufnagel, L. (2000): Bioindikáció vízi gerinctelenekkel a Dunában 4. Heteroptera fajegyüttesek hasonlósági mintázata a Dunán. — Hidrológiai Közlöny 80: 288290.

[18] Dévényi, L. (1989): A Ráckevei (Soroksári) Duna környezetvédelmi helyzete. Hidrológiai Tájékoztató 29: 28-30.

[19] Dvihally, Zs. (ed.) (1987): A kisalföldi Duna-szakasz ökológiája. — VEAB.

[20] Fábián György(1972): Haljelölések a soroksári Duna-ágban. — Halászat 65: 88-89

[21] Fekete, J., Morovján, Gy., Ratkai, T., Hollósi, M. (1994): Long-term evaluation of the water quality of the Ráckeve-Soroksár Danube arm. - Acta biologica Debrecina-supplementum oecologica hungarica 5: 109-117.

[22] Fürész György (1982): Haltermelés a Ráckevei Dunaág hullámterén. — Halászat, 75: 73-74.

[23] Gulyás, P., Thyahun, Sz. (1974): Adatok a Ráckevei Duna-ág kisrák faunájához. Hidrológiai Közlöny 54: 240-245.

[24] Gulyás, P. (1997): Untersuchungen des Rotatoria- und Crustacea-Planktons an der Donaustrecke unterhalb Budapest sowie im Donauarm Ráckevei-Soroksári Duna (RSD). 32. Konferenz der IAD, Wien-Österreich 1997. Wissenschaftliche Referate 265-270.

[25] Gulyás, P. (2002): A Rotatoria és Crustacea plankton minőségi és mennyiségi vizsgálata a Dunán. Vízügyi Közlemények 84: 601-620.

[26] Győrbíró, T. (1974): A Ráckevei-Soroksári Duna halgazdálkodása. Diplomadolgozat.

[27] Haitman, K. (1990): A Ráckevei Duna vízminőségéről. — Halászat 83: 107-108.

[28] Halász, M. (1936): Adatok a soroksári Dunaág algavegetációjának ismeretéhez. Botanikai Közlemények 33: 139-181.

[29] Halász, M. (1937): A soroksári Dunaág Bacillariái I. — Botanikai Közlemények 34: 204222. 
[30] Hollósy, M. (1995): A Ráckevei-Soroksári Dunaág vízminőségének vizsgálata. Hidrológiai Közlöny, 75/2: 94-98.

[31] Hollósy Miklós - Fekete Jenő - Horváth Kornélia - Ratkai Tünde - Morovján György (1996): Olajszennyezés eredetének meghatározása kombinált módszerekkel a Ráckevei Duna-ágon. - Hidrológiai Közlöny 76: 369-373.

[32] Horváth László (1968): Gondolatok a Soroksári Duna-ág halfaunájáról. — Halászat 61: 159.

[33] Horváth László (1968): Gondolatok a soroksári Duna-ág halgazdálkodásáról. — Halászat 61: 47.

[34] Hufnagel, L. (1998): Data to the knowledge of the aquatic, semiaquatic and shore bug fauna of Budapest and the country Pest (Heteroptera: Nepomorpha, Gerromorpha, Leptopodomorpha). - Folia Entomologica Hungarica 59: 29-34.

[35] Just, I., Schöll, F, Tittizer, T. szerk. (1998): Versuch einer Harmonisierung nationaler Methoden zur Bewertung der Gewassergüte im Donauarm am Beispiel der Abwasser der Stadt Budapest. - Umweltbundesamt, Berlin.

[36] Kalmár, J., Petrescu, I., Vicze, M. (2005): Bronzkori Duna-ág a Csepel-szigeten. Hidrológiai Közlöny 85: 46-50.

[37] Kárpáti, I. (1958): A hazai Duna-ártér erdőtípusai. — Az erdő 7: 307-318.

[38] Kárpáti, I (1962): Az Urtica kiovensis előfordulása és termőhelyi viszonyai a Soroksári Duna-ágban. — Botanikai Közlemények 49: 329-330.

[39] Kárpáti Vera (1963): Die zönologischen und ökologischen Verhältnisse der Wasservegetation des Donau-Überschwemmungsraumes in Ungarn. - Acta botanica Hungarica 9: 323-385.

[40] Kiss, K. T. (1984): Occurrence of Thalassiosira pseudonana Hasle et Heimdal (Bacillariophyceae) in some rivers of Hungary. - Acta botanica Hungarica 30: 277-287.

[41] Kiss, K. T., Genkal, S. I. (1993): Winter blooms of centric diatoms in the River Danube and in its side-arms near Budapest (Hungary). - Hydrobiologia 269/270: 317-325.

[42] Kiss, K. T. Pápista, É., Ács, É., Makk. J., (2000): Comparison of phytoplankton of 80s and late $90 \mathrm{~s}$ in a large side arm of the Danube River (Soroksár-Daube - Hungary). Limnological Reports 33: 103-110.

[43] Kontschán, J., B. Muskó I., Murányi D. (2002): A felszíni vizekben előforduló felemáslábú rákok (Crustacea: Amphipoda) rövid határozója és előfordulásuk Magyarországon. — Folio Historico Naturalia Musei Matraensis 26: 151-157.

[44] Kovács J. Gy.(1973): Fővárosunk tava a ráckevei (soroksári) Duna. — Vízgazdálkodás 13: 215-220.

[45] Kovács, T. (2005): Data to the Hungarian mayfly (Ephemeroptera) fauna arising from collectins of larvae III. - Folio Historico Naturalia Musei Matraensis 29: 101-110.

[46] Kovács, T., Juhász, P., Ambrus, A. (2005): Adatok a Magyarországon élő folyami rákok (Decapoda: Astacidae, Cambaridae) elterjedéséhez. — Folio Historico Naturalia Musei Matraensis 29: 85-89.

[47] Lesenyei, J. (1954): A soroksári Dunaág vízminőségének vizsgálata. — Vízügyi Közlemények, 36: 219-229.

[48] Litheráthy, P., Koller-Kreimer, V., Liska, I. (2002): Joint Danube Survey. Technical Report of the International Commission for the Protection of the Danube River. - International Commission for the Protection of the Danube River, Vienna International Centre.

[49] Lóki, J. (1997): A dunai Alföld. — In: Karátson Dávid (ed.): Magyarország földje — Kitekintéssel a Kárpát-medence egészére. Magyar Könyvklub, Budapest pp. 320321.

[50] Marosi, S., Somogyi, S. (ed). (1990): Magyarország kistájainak katasztere. — MTA Földrajztudomány Kutató Intézet, Budapest, vol. I, pp. 38-43.

[51] Móra, A., Dévai, Gy. (2004): Magyarország árvaszúnyog-faunájának (Diptera:Chironomidae) jegyzéke az előfordulási adatok és sajátosságok 
feltüntetésével. - Acta biologica Debrecina-supplementum oecologica hungarica 12:39-207.

[52] Némedi, L., Török, P., Pietraskó, G. (1981): A ráckevei (soroksári) Duna-ág bakterológiai vízminőségét meghatározó budapesti szennyező források. — Hidrológiai Közlöny 61: 560565.

[53] Palik, P. (1961): Beitrage zur Algenvegetation an den Betonbauten in der Donau. Annales Universitatis Scientiarum Budapestinensis de Rolando Eötvös nominatae, Danubialia Hungarica 10: 139-150.

[54] Papp, Sz. (1961): Felszíni vizeink minősége. — Hidrológiai Közlöny 41: 188-209.

[55] Papp, K., Fábián, E. (1974): Vízminőség, Telepítés, Fogás. — Horgász kalaúz — MOHOSZ press, pp. 103-105.

[56] Péter Gyula (1978): A ráckevei (Soroksár) Duna hasznosításának vizsgálata. Vízgazdálkodás és Környezetvédelem 5: 81-86.

[57] Pintér, L., Richnovszky, A., Szigethy, A. (1979): A magyarországi recens puhatestûek elterjedése. - Soósiana Suppl. 1:1-351.

[58] Pintér, L., Szigethy, A. (1979): Die Verbreitung der rezenten Mollusken Ungarns: Neunachweise und Berichtigungen I. - Soósiana 7:97-108.

[59] Pintér, L., Szigethy, A. (1980): Die Verbreitung der rezenten Mollusken Ungarns: Neunachweise und Berichtigungen II. - Soósiana 8:65-80.

[60] Puky, M., Schád, P., Szövényi, G. (2005): Magyarország herpetológiai atlasza. — Varangy Akciócsoport Egyesület, Budapest.

[61] Rácz Béla(1967): A Balaton és a Soroksári Duna-ág halállományának vizsgálata jelöléssel. — Halászat 60: 54-55.

[62] Ribiánszky Miklós(1977): A Ráckevei (Soroksári)-Dunaág halgazdálkodási adottságai. — Halászat 70: 38-40.

[63] Richnovszky, A. (1967): Data to the mollusk fauna of the flood area of the Danube. (Danubialia Hungarica, XLII). - Opuscula zoologica Budapest 1: 195-205.

[64] Schiefner, K., Urbányi, A. (1970): A Soroksári Duna-ág komplex higiénés vizsgálata. — Hidrológiai Közlöny 50: 318-324.

[65] Somogyi, S. (1997): A Duna, a Tisza és a mellékfolyóik. — In: Karátson Dávid (ed.): Magyarország földje - Kitekintéssel a Kárpát-medence egészére. Magyar Könyvklub, Budapest, pp. 261-266.

[66] Stefanovits, P. (1999): A tájak talajviszonyai. — In: Stefanovits, P., Filep, Gy., Füleky, Gy.: Talajtan. Mezőgazda Kiadó, Budapest, pp. 406-438.

[67] Steinmann, H. (1962): A magyarországi szitakötők faunisztikai és etológiai adatai. — Folia Entomologica Hungarica 1: 141-198.

[68] Szabó, I. (1974): A ráckevei (soroksári) Duna és üdülőkörzete vízgazdálkodás-fejlesztési terve. - Vízügyi Közlemények 56: 291-298.

[69] Szabó, K. Ács, É., Pápista, É., Kiss, K.T., Barreto, S., Makk. J. (2001): Periphyton and phytoplankton in the Soroksár-Danube in Hungary. I. Periphytic algae on reed stems. Acta Botanica Hungarica 43: 13-35.

[70] Töröcsik, Gy. (1961): A soroksári Duna-ág vízgazdálkodási jelentősége. — Hidrológiai Tájékoztató 1: 46-47.

[71] Tyahun, Sz. (1970): Angaben zur Kenntnis der Hydrocarina-Fauna Ungarns, nebst Beschreibung einer neuen Arrenurus-Art. — Opuscula Zoologica Budapest 10: 349-358.

[72] Tyahun, Sz. (1972): A mezofauna populáció-dinamikai vizsgálata a Soroksári Dunaág hínárosaiban. Manuscript, Budapest: 1-81. Doktori értekezés

[73] Thyahun, Sz. (1977): Populatiodynamische Untersuchungen der Mesofauna in den Laichkrautbestanden des Donauarms von Soroksár. - Opuscula Zoologica Budapest 13: 83-106.

[74] Ujhelyi, S. (1971): Adatok a Leptoceridae (Trichoptera) család fajainak magyarországi elterjedéséhez. — Folia Entomologica Hungarica 24: 119-136. 
[75] Ujhelyi, S. (1982): Ein Beitrag zur Verbreitung der Hydropsyche-Arten (Trichoptera) in Ungarn. - Folia Entomologica Hungarica 43: 191-203.

[76] Ulrich, E., Csanády, M., Deák, Zs., Pénzes, M., Bencze, E. (1977): Adatok a Pest megyei Duna-szakasz szabad strandjainak vízminőségére. - Hidrológiai Közlöny 57: 97-104.

[77] Varga, P., Steindl, Zs., Tyahun, Sz. (1985): Adatok a Ráckevei (Soroksári) Dunaág vízminőségéhez. - IAD. Bratislava, pp. 225-278.

[78] Varga, A., Csányi, B. (1997): Vízicsiga-fajok elterjedésének adatai hazai folyóinkban az elmúlt évtized faunisztikai feltárása alapján. - Folio Historico Naturalia Musei Matraensis 22: $285-322$.

[79] Varga, A., Csányi, B., Majoros, G. (1999): Kagylófajok elterjedésének adatai hazai folyóinkban az elmúlt évtized faunisztikai feltárása alapján II. (Mollusca - Bivalvia). Folio Historico Naturalia Musei Matraensis 23: 347-367.

[80] Veszprémi Béla (1976): A Ráckevei Duna halászbiológiai vizsgálata. — Halászat 69. 82-83.

[81] Veszprémi Béla (1976): A Ráckevei Duna halászatbiológiai vizsgálata. II. rész. — Halászat 69: 118-119.

[82] Woynárovich, E. (1954): Vorkommen der Limnomysis benedeni Czern. im ungarischen Donauabschnitt. - Acta Zoologica Hungarica 1:177-185.

[83] Woynárovich Elek(1956): Mi történik a Soroksári Dunaágban? — Halászat. 3: 60.

\section{REPORTS}

[84] Dolánszky, F. (1969): Szakvélemény a Soroksári Duna vízminőségéről. VITUKI, témajelentés.

[85] Felföldy, L. (1975): Hidrobiológiai tanulmány a Ráckevei (Soroksári) Dunaág vízminőségvédelmi tervéhez. VITUKI, témajelentés.

[86] Gánti, T. (1997): Ráckevei (Soroksári) Duna-ág kavics-kitermelés és vízerőhasznosítás. Elözetes környezeti hatástanulmány I. kötet, Állapotfelmérés 1.rész. KOGITÁTOR GMK, Nagymaros.

[87] GEOSAURUS Kft. (2002): A Ráckevei (Soroksári) Duna tervezett mederkotrásainak várható hatásai. Részletes környezeti hatásvizsgálat, Budapest.

[88] KDV-KÖVIZIG (1997): Az RSD vízminőségi célállapotának meghatározása. Budapest.

[89] KHVM (1996): A Ráckevei-Soroksári Duna komplex vízminőségjavító programja. Témajelentés.

[90] NOVUM Kft. (2000): A Ráckevei (Soroksári) Duna környezeti állapotának felmérése és a tervezett mederkotrások ökológiai, környezetvédelmi hatásai. Elözetes környezeti hatástanulmány. Budapest.

[91] Szabó, Z. (1954): A Soroksári Dunaág szennyezettsége. VITUKI, témajelentés.

[92] Váradi, L. (2003): A pontyállomány természetes szaporodásának vizsgálata a Ráckevei Duna-ágon. SZIE-RDHSZ, témabeszámoló.

\section{Web references}

[93] IAD — International Association for Danube Research: www.iad.gs

[94] KDV-KÖVIZIG — Közép-Duna-völgyi Környezetvédelmi és Vízügyi Igazgatóság (Central Danube Valley Environmental and Water Authority): www.kdvvizig.hu

[95] MOHOSZ - Magyar Országos Horgász Szövetség (National Federation of Hungarian Anglers): www.mohosz.hu

[96] RDHSZ — Ráckevei Duna-ági Horgász Szövetség (Ráckeve Danube-branch Angling Society): www.rdhsz.hu 


\section{APPENDIX \\ THE FAUNA OF THE RÁCKEVE-SOROKSÁG DANUBE}

\section{ROTATORIA}

Ascomorpha ecaudis Perty, 1850

Asplanchna priodonta Gosse, 1850

Brachionus angularis Gosse, 1851

Brachionus budapestinensis Daday, 1885

Brachionus calyciflorus calyciflorus Pallas, 1766

Brachionus calyciflorus amphiceros Ehrenberg, 1838

Brachionus calyciflorus anuraeiformis Brehm, 1909

Brachionus calyciformis spinosus Rousselet, 1901

Brachionus diversicornis (Daday, 1883)

Brachionus leydigi tridentatus (Sernov, 1901)

Brachionus forficula Wierzejsky, 1891

Brachionus falcatus Zacharias, 1898

Brachionus quadridentatus quadridentatus Hermann, 1783

Brachionus quadridentatus brevispinus Ehrenberg, 1832

Brachionus quadridentatus cluniorbicularis Skorikov, 1894

Brachionus urceolaris (O. F. Müller, 1773)

Euchlanis dilatata (Ehrenberg, 1832)

Filinia longiseta (Ehrenberg, 1834)

Filinia terminalis (Plate, 1886)

Kelikottia longispina (Kellicott, 1879)

Keratella cochlearis cochlearis (Gosse, 1851)

Keratella cochlearis tecta (Gosse, 1851)

Keratella quadrata (O. F. Müller, 1786)

Keratella serrulata (Ehrenberg, 1838)

Lecane bulla (Gosse, 1886)

Lecane luna (O. F. Müller, 1776)

Lecane lunaris (Ehrenberg, 1832)

Lecane quadridentata (Ehrenberg, 1832)

Lophocharis salpina (Ehrenberg, 1834)

Mytilina mucronata (O. F. Müller, 1773)

Mytilina ventralis (Ehrenberg, 1832)

Notholca acuminata (Ehrenberg, 1832)

Notholca squamula (O. F. Müller, 1786)

Platyas quadricornis (Ehrenberg, 1832)

Pompholyx complanata Gosse, 1851

Polyarthra vulgaris Carlin, 1943

Synchaeta pectinata Ehrenberg, 1832

Testudinella patina (Hermann, 1783)

Trichocerca pusilla (Lauterborn, 1898)

\section{CNIDARIA}

Hydra vulgaris Pallas, 1766

\section{TURBELLARIA}

Planaria (Dugesia) lugubris (O. Schmidt, 1861)

\section{ANNELIDA}

Alboglossiphonia heteroclita (Linnaeus, 1761)

Criodrilus lacuum Hoffmeister, 1845 
Dina apathyi Gedroyc, 1916

Dina lineata (O. F. Müller, 1774)

Erpobdella nigricollis (Brandes, 1900)

Erpobdella octoculata (Linnaeus, 1758)

Glossiphonia complanata (Linnaeus, 1758)

Glossiphonia paludosa (Carena, 1824)

Glossiphonia heteroclita (Linnaeus, 1785)

Haemopis sanguisuga (Linnaeus, 1758)

Helobdella stagnalis (Linnaeus, 1758)

Hemiclepsis marginata (O. F. Müller, 1774)

Piscicola geometra (Linnaeus, 1761)

Theromyzon tessulatum (O. F. Müller, 1774)

Chaetogaster diaphanus (Gruithuisen, 1828)

Stylaria lacustris (Linnaeus, 1767)

Nais obtusa (Gervias, 1838)

Nais pardalis Piguet, 1906

Ophidonais serpentina (O. F. Müller, 1773)

Dero dorsalis Ferronniere, 1899

\section{MOLLUSCA}

\section{GASTROPODA}

Acroloxus lacustris (Linnaeus, 1758)

Ancylus fluviatilis (O.F. Müller, 1774)

Anisus vortex (Linnaeus, 1758)

Anisus vorticulus (Troschel, 1834)

Anisus septemgyratus (Rossmassler, 1835)

Aplexa hypnorum (Linnaeus, 1758)

Armiger crista (Linnaeus, 1758)

Bathyomphalus contortus (Linnaeus, 1758)

Bithynia tentaculata (Linnaeus, 1758)

Bithynia leachi (Sheppard, 1823)

Fagotia esperi (Ferussac, 1823)

Ferrissia wautieri Mirolli, 1960

Gyraulus albus (O. F. Müller, 1774)

Galba palustris O. F. Müller, 1774

HIPPEUTIS COMPLANATUS (LINNAEUS, 1758)

Lithoglyphus naticoides (Pfeiffer, 1828)

Lymnaea stagnalis (Linnaeus, 1758)

Lymnaea palustris (O. F. Müller, 1774)

Lymnaea peregra (O. F. Müller, 1774)

Physa fontinalis (Linnaeus, 1758)

Physella acuta (Draparnaud, 1805)

Planorbarius corneus (Linnaeus, 1758)

Planorbis carinatus O. F. Müller, 1774

Planorbis planorbis (Linnaeus, 1758)

Potamopyrgus jenkinsi (Smith, 1889)

Radix auricularia (Linnaeus, 1758)

Radix ovata (Draparnaud, 1805)

Radix peregra ovata O. F. Müller, 1774

Segmentina nitida (O. F. Müller, 1774)

Stagnicola turricula (Held, 1836)

Theodoxus transversalis (Pfeiffer, 1828)

Valvata cristata O. F. Müller, 1774

Valvata piscinalis (O. F. Müller, 1774)

Valvata natacina (Menke, 1854)

Viviparus acerosus (Bourguignat, 1862)

Viviparus contectus (Millet, 1813) 


\section{BIVALVIA}

Unio crassus Retzius, 1788

Unio pictorum (Linné, 1758)

Unio tumidus (Retzius, 1788)

Sinanodonta woodiana (Lea, 1834)

Sphaerium corneum (Linnaeus, 1758)

Pseudanodonta complanata (Rossmassler, 1835)

Pisidium supinum (Schmidt, 1851)

Pisidium amnicum (O.F. Müller, 1774)

Pisidium henslowanum (Sheppard, 1823)

Pisidium moitessierianum (Paladilhe, 1866)

Pisidium nitidum (Jenyns, 1832)

Pisidium subtruncatum (Malm, 1855)

Dreissena polymorpha (Pallas, 1771)

Anodonta anatina (Linnaeus, 1758)

Anodonta cygnea (Linnaeus, 1758)

Musculium lacustre (O. F. Müller, 1774)

\section{CRUSTACEA}

\section{COPEPODA}

Attheyella trispinosa (Brady, 1880)

Canthocamptus staphylinus (Jurine, 1820)

Macrocyclops albidus (Jurine, 1820)

Macrocyclops fuscus (Jurine, 1820)

Eucyclops serrulatus (Fischer, 1851)

Eucyclops macruroides (Lilljeborg, 1901)

Eucyclops macrurus (Sars 1863)

Paracyclops fimbriatus (Fischer, 1853)

Cyclops strenuus Fischer, 1851

Cyclops vicinus Uljanin, 1875

Cyclops unisetiger (Graeter, 1908)

Megacyclops viridis (Jurine, 1820)

Acanthocyclops vernalis (Fischer, 1853)

Acanthocyclops robustus (Sars, 1863)

Diacyclops bicuspidatus (Claus, 1857)

Microcyclops bicolor (Sars, 1863)

Mesocyclops leuckarti (Claus, 1857)

Thermocyclops crassus (Fischer, 1853)

Thermocyclops oithonoides (Sars, 1863)

Eudiaptomus gracilis (Sars, 1863)

Eurytemora velox (Lilljeborg, 1853)

Ectocyclops phaleratus (Koch, 1838)

\section{CLADOCERA}

Alona tenuicaudis Sars, 1862

Alonella nana (Baird, 1850)

Anchistropus emarginatus Sars, 1862

Bosmina longirostris (O. F. Müller, 1785)

Bosmina coregoni Baird, 1857

Camptocercus rectirostris Schoedler, 1862

Leptodora kindti (Focke, 1844)

Sida crystallina (O. F. Müller, 1776)

Diaphanosoma brachyurum (Lievin, 1848)

Daphnia cucullata Sars, 1862

Daphnia hyalina Leydig, 1860

Daphnia longispina O. F. Müller, 1785

Disparalona rostrata (Koch, 1841)

Eurycercus lamellatus (O. F. Müller, 1785) 
Graptoleberis testudinaria (Fischer, 1848)

Simocephalus serrulatus (Koch, 1841)

Simocephalus vetulus (O. F. Müller, 1776)

Moina macrocopa (Straus, 1820)

Moina micrura Kurz, 1874

Moina rectirostris Leydig, 1860

Monospilus dispar Sars, 1862

Ceriodaphnia quadrangula (O. F. Müller, 1785)

Ceriodaphnia dubia Richard, 1894

Ceriodaphnia laticaudata (P .E. Müller, 1867)

Ceriodaphnia pulchella Sars, 1862

Scapholeberis mucronata (O. F. Müller, 1785)

Macrothrix laticornis (Fischer, 1848)

Macrothrix hirsuticornis Norman \& Brady, 1867

Iliocryptus sordidus (Lievin, 1848)

Iliocryptus agilis Kurz, 1878

Acroperus harpae (Baird, 1834)

Peracantha truncata (O. F. Müller, 1758)

Leydigia leydigi (Schoedler, 1863)

Chydorus sphaericus (O. F. Müller, 1776)

Pleuroxus trigonellus (O. F. Müller, 1785)

Pleuroxus uncinatus Baird, 1850

Pleuroxus aduncus (Jurine, 1820)

Pseudochydorus globosus (Baird, 1843)

Alona quadrangularis (O. F. Müller, 1785)

Alona affinis (Leydig, 1860)

Alona intermedia Sars, 1862

Alona guttata Sars, 1862

Alona rectangula Sars, 1862

OSTRACODA

Cypridopsis vidua (O. F. Müller, 1776)

Cypria ophthalmica (Jurine, 1820)

AMPHIPODA

Dikerogammarus villosus (Sovinski, 1894)

Niphargus hrabei Karaman, 1932

Orconectes limosus (Rafinesque, 1817)

BRANCHIURA

Argulus foliaceus Linnaeus, 1758

ISOPODA

Asellus aquaticus (Linnaeus, 1758)

MYSIDA

Limnomysis benedeni Czerniavsky, 1882

\section{HETEROPTERA}

Plea minutissima minutissima Leach, 1817

Micronecta scholtzi (Fieber, 1860)

Micronecta meridionalis (Costa, 1862)

Micronecta pusilla (Horváth, 1895)

Ilyocoris cimicoides (Linnaeus, 1758)

Callicorixa praeusta praeusta (Fieber, 1848)

Callicorixa concinna (Fieber, 1848)

Cymatia coleoptrata (Fabricius, 1777)

Cymatia rogenhoferi (Fieber, 1864)

Sigara falleni (Fieber, 1848)

Sigara striata (Linnaeus, 1758)

Ranatra linearis (Linnaeus, 1758) 
Gerris argentatus Schummel, 1832

Microvelia reticulata (Burmeister, 1835)

Hebrus pusillus (Fallén, 1807)

Hesperocorixa linnaei (Fieber, 1848)

Nepa cinerea Linnaeus, 1758

\section{MEGALOPTERA}

Sialis fuliginosa Pictet, 1836

\section{ODONATA}

Platycnemis pennipes (Pallas, 1771)

(Coen)Agrion puella (Linnaeus, 1758)

Crocothemis erythraea erythraea Brullé, 1832

Erythromma najas (Hansemann, 1823)

Enallagma cyathigerum Charpentier, 1840

Ischnura pumilio (Charpentier, 1825)

Ischnura elegans (Van der Linden, 1820)

Anax imperator Leach, 1815

Sympetrum striolatum striolatum (Charpentier, 1840)

Orthetrum cancellatum cancellatum (Linnaeus, 1758)

\section{EPHEMEROPTERA}

Cloeon dipterum (Linnaeus, 1761)

Caenis horaria (Linnaeus, 1758)

Caenis macrura Stephens, 1835

Caenis robusta Eaton, 1884

Potamanthus luteus (Linnaeus, 1767)

\section{ACARI}

Georgella koenikei Maglio, 1906

Hydrodroma despiciens (O. F. Müller, 1776)

Hydrachna globosa (De Geer, 1778)

Oxus strigatus (O. F. Müller, 1776)

Limnesia undulata (O. F. Müller, 1776)

Limnesia fulgida Koch, 1836

Unionicola aculeata (Koenike, 1890)

Unionicola crassipes (O. F. Müller, 1776)

Mideopsis obricularis (O. F. Müller, 1776)

Neumania deltoides (Piersig, 1894)

Neumania limosa (Koch, 1836)

Neumania vernalis (O. F. Müller, 1776)

Piona coccinea (Koch, 1836)

Piona conglobata (Koch, 1836)

Piona longipalpis (Krendowskij, 1878)

Piona pusilla Neuman, 1875

Piona variabilis (Koch, 1836)

Arrenurus abbreviator (Berlese, 1888)

Arrenurus bruzelii Koenike, 1885

Arrenurus crassicaudatus Kramer, 1875

Arrenurus globator (O. F. Müller, 1776)

Arrenurus integrator (O. F. Müller, 1776)

Arrenurus cuspidifer Piersig, 1896

Arrenurus sinuator (O. F. Müller, 1776)

Arrenurus tricuspidator (O. F. Müller, 1776)

Arrenurus furciger Viets, 1935

Eylais extendens (O. F. Müller, 1776)

Hydrozetes parisiensis Grandjean, 1948

Hydrozetes lemnae (Coggi, 1899) 


\section{TRICHOPTERA}

Mystacides nigra (Linnaeus, 1758)

Stactobia eatoniella McLachlan, 1880

Cyrnus flavidus McLauchlan, 1864

Ecnomus tenellus (Rambur, 1842)

Setodes tineiformis Curtis, 1834

ARANEIDEA

Argyroneta aquatica (Clerck, 1757)

\section{CHIRONOMIDAE}

Endochironomus albipennis (Meigen, 1830)

Dicrotendipes nervosus (Staeger, 1839)

Tanypus punctipennis Meigen, 1818

Procladius choreus (Meigen, 1804)

Procladius rufovittatus (van der Wulp, 1874)

Procladius ferrugineus Kieffer, 1919

Chironomus nudiventris Ryser, Scholl et Wülker, 1983

Chironomus obtusidens Goetghebuer, 1921

Chironomus plumosus (Linnaeus, 1758)

Cryptochironomus defectus (Kieffer, 1913)

Microchironomus tener (Kieffer, 1918)

Parachironomus frequens (Johannsen, 1905)

Tanytarsus huesdensis Goetghebuer, 1923

Polypedilum sordens (van der Wulp, 1874)

Cricotopus sylvestris (Fabricius, 1794)

\section{COLEOPTERA}

Acilius sulcatus (Linnaeus, 1758)

Haliplus fluviatilis Aubé, 1836

Laccophilus hyalinus (De Geer, 1774)

Noterus crassicornis (O. F. Müller, 1776)

Noterus clavicornis (De Geer, 1774)

Hydroglyphus geminus (Fabricius, 1792)

Laccobius minutus (Linnaeus, 1758)

Limnebius nitidus (Marsham, 1802)

\section{VERTEBRATA}

\section{PISCES}

Eudontomyzon mariae Berg, 1931

Acipenser ruthenus Linnaeus, 1758

Salmo trutta $m$. fario Linnaeus, 1758

Oncorhinchus mykiss (Walbaum, 1792)

Esox lucius Linnaeus, 1758

Rutilus rutilus (Linnaeus, 1758)

Ctenopharyngodon idelle (Valenciennes, 1844)

Scardinius erythrophthalmus Linnaeus, 1758

Leuciscus leuciscus (Linnaeus, 1758)

Leuciscus cephalus (Linnaeus, 1758)

Leuciscus idus Linnaeus, 1758

Aspius aspius (Linnaeus, 1758)

Leucaspius delineatus Heckel, 1843

Blicca bjoerkna (Linnaeus, 1758)

Abramis brama (Linnaeus, 1758)

Abramis ballerus (Linnaeus, 1758)

Abramis sapa (Pallas, 1811)

Vimba vimba (Linnaeus, 1758)

Pelecus cultratus (Linnaeus, 1758) 
Tinca tinca (Linnaeus, 1758)

Chondrostoma nasus (Linnaeus, 1758)

Barbus barbus (Linnaeus, 1758)

Gobio gobio (Linnaeus, 1758)

Gobio albipinnatus Lukasch, 1933

Pseudorasbora parva (Temminck \& Schlegel, 1846)

Rhodeus sericeus amarus (Bloch, 1782)

Carassius carassius Linnaeus, 1758

Carassius auratus (Linnaeus, 1758)

Cyprinus carpio Linnaeus, 1758

Hypophtalmichthys molitrix (Valenciennes, 1844)

Aristichthys nobilis (Richardson, 1845)

Noemacheilus barbatulus (Linnaeus, 1758)

Misgurnus fossilis (Linnaeus, 1758)

Alburnus alburnus (Linnaeus, 1758)

Cobitis taenia Linnaeus, 1758

Sabanejewia aurata Filippi, 1865

Silurus glanis Linnaeus, 1758

Ictalurus nebulosus (LeSueur, 1819)

Anguilla anguilla (Linnaeus, 1758)

Lota lota (Linnaeus, 1758)

Gasterosteus aculeatus Linnaeus, 1758

Lepomis gibbosus (Linnaeus, 1758)

Perca fluviatilis Linnaeus, 1758

Gymnocephalus cernuus (Linnaeus, 1758)

Gymnocephalus schraetzer (Linnaeus, 1758)

Gymnocephalus baloni Holcik \& Hensel, 1974

Stizostedion lucioperca (Linnaeus, 1758)

Stizostedion volgense (Gmelin, 1788)

Zingel zingel (Linnaeus, 1766)

Zingel streber (Siebold, 1863)

Proterorhinus marmoratus (Pallas, 1814)

Neogobius kessleri Günther, 1861

Neogobius fluviatilis (Pallas, 1814)

Umbra krameri Walbaum, 1792

AMPHIBIA

Triturus dobrogicus Kiritzescu, 1903

Triturus vulgaris Linnaeus, 1758

Bombina bombina Linnaeus, 1761

Pelobates fuscus Laurenti, 1768

Bufo bufo Linnaeus, 1758

Bufo viridis Laurenti, 1768

Hyla arborea Linnaeus, 1758

Rana arvalis Nilsson, 1842

Rana dalmatina Bonaparte, 1840

Rana ridibunda Pallas, 1771

Rana esculenta Linnaeus, 1758

REPTILIA

Emys orbicularis Linnaeus, 1758

Trachemys scripta elegans Seidel, 2002

Natrix natrix Linnaeus, 1758

Natrix tessellata Laurenti, 1768 